\title{
22. PETROLOGY OF ORGANIC MATTER, DEEP SEA DRILLING PROJECT SITE 415 and 416, MOROCCAN BASIN, EASTERN NORTH ATLANTIC
}

\author{
Chris Cornford, ${ }^{1}$ Erdöl and Organische Geochemie, Kernforschungsanlage Jülich, 4170 Jülich, \\ Federal Republic of Germany
}

\begin{abstract}
Nine samples were analyzed using reflected-light microscopy techniques to determine the type and maturity of the sedimentary organic matter. The vitrinite-huminite reflectance values reached about 0.45 per cent at terminal depth $(1624 \mathrm{~m})$ indicating an immature sediment section. A high amorphous (aquatic) kerogen content in allochthonous upper Oligocene (Site 415) and Cenomanian and Hauterivian (Sites 415,416 ) sediments suggests their deposition under oxygenminimum conditions prior to transport from the shelf-edge environments. The Valanginian and Tithonian sediments contain small amounts of dominantly vitrinitic (terrestrial) kerogen which, as at Site 398 , is in part recycled organic matter.
\end{abstract}

\section{INTRODUCTION}

During DSDP-IPOD Leg 50 two sites were drilled about $100 \mathrm{~km}$ off the Moroccan coast (Figure 1). The first, Site 415 , penetrated about 460 meters of Tertiary sediments unconformably overlying about 590 meters of Cenomanian-Albian and possibly younger Cretaceous sediments. Total penetration was 1079 meters (Figure 2A). In this study one sample from the lower Miocene and two samples from Cenomanian and possibly younger sediments were analyzed with a reflected-light microscope to determine type and maturity of organic matter. Drilling at the second site, Site 416 , penetrated about 760 meters of Tertiary sediments unconformably overlying Cenomanian-Tithonian sediments which extended to a total depth at 1624 meters (Figure 2B). One sample of upper Oligocene sediment and five samples of Hauterivian to Tithonian sediment were analyzed.

The study of the organic matter in these sediments by microscopic techniques provides information on the type and maturity of the organic matter in the sediments. The quantity of organic matter present is determined from the organic-carbon content. This information can be related to provenance, depositional environment, and thermal history of the sediments, and thus to their hydrocarbon potential.

\section{EXPERIMENTAL PROCEDURES}

The details of the experimental procedures have been described in an earlier report (Cornford et al., in press). Briefly, each sample is ground, treated with hydrochlor-

\footnotetext{
${ }^{1}$ Present address: British National Oil Corporation, Glasgow,
}

ic acid, and an organic concentrate floated off on a high-density $\left(1.95 \mathrm{~g} / \mathrm{cm}^{3}\right)$ solution. The organic concentrate is then embedded in "araldite" resin, polished, and studied using a reflected-light microscope equipped with oil-immersion objectives. Reflectance $(R)$ measurements are then made on between 50 and 100 vitrinitehuminite particles per sample using nonpolarized light. The measurements are displayed as a histogram (number of counts per 0.05 per cent $R$ interval, e.g., Figure 3 ). An arithmetic mean and standard deviation are calculated for each discrete population in the histogram and the mean reflectance value for the lowest vitrinite-huminite reflectance population in each sample is plotted (on a log scale) against depth (on a linear scale).

The macerals (types of organic particles) are determined for each sample using reflected light to identify vitrinite and inertinite, complemented by ultraviolet excitation-fluorescence for characterization of liptinites (Stach et al., 1975). Liptinites are then subdivided into amorphous matter, ascribed to an algal origin, and characteristic particles of higher-plant origin such as spores, cuticle, resin, and pollen.

\section{RESULTS}

Vitrinite-reflectance histograms for Sites 415 and 416 are shown in Figures 3 and 4, respectively. Reflectance data are summarized in Table 1. The mean reflectance values are plotted (log scale) as a function of depth in Figure 5 for both Sites 415 and 416 . Figure 5 also shows the approximate down-hole temperature of the section at Site 416 only. Plotting the reflectance values of both sites on a single trend line seems valid since the sites are relatively closely spaced (Figure 1) and both sets of samples fall approximately on a single depth-reflec- 


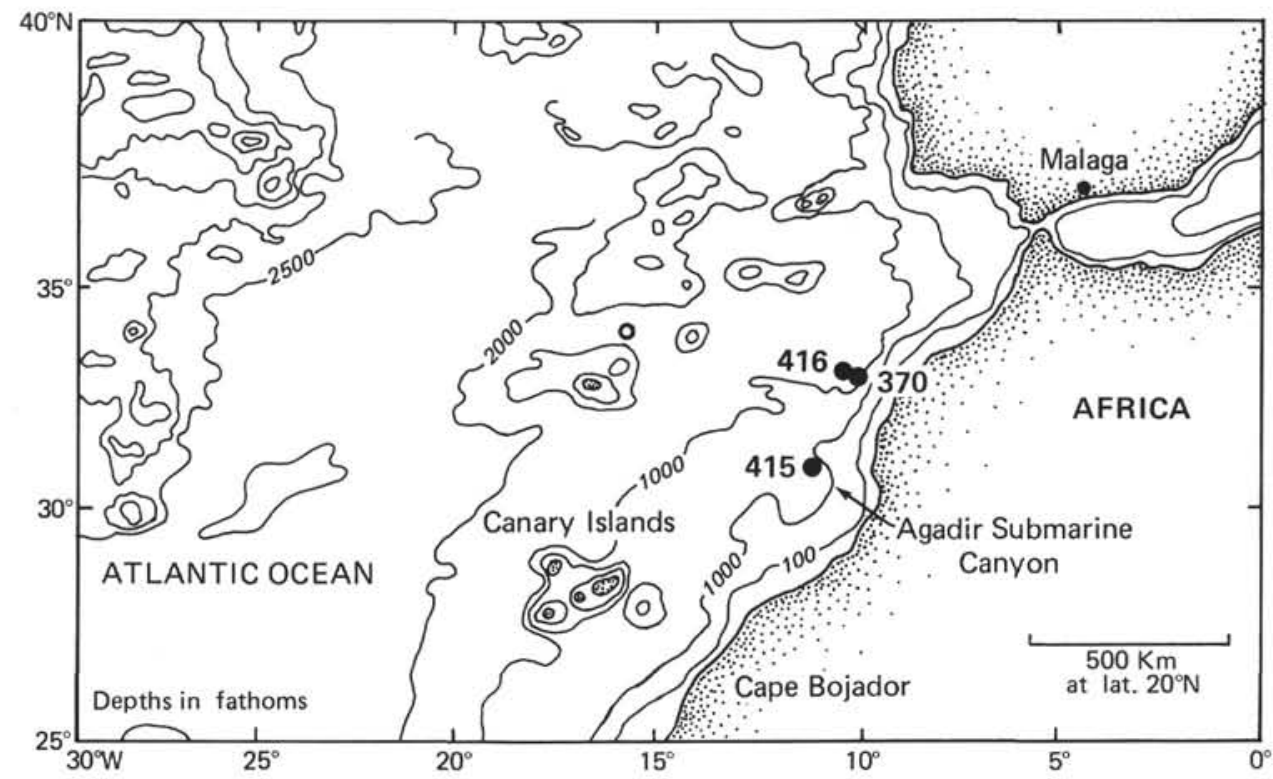

Figure 1. Location of DSDP Sites 415 and 416.

tance trend line. The type of the organic matter present is summarized in Table 2 .

\section{DISCUSSION}

\section{Maturity}

The maturity of the sediments is indicated by the vitrinite-huminite reflectance trend in Figure 5. The values for Sites 415 and 416 fall on a single trend line, showing a similar maturity gradient at both sites. The reflectance trend reaches about 0.45 per cent $R$ at 1600 meters, indicating an immature overlying sediment column, with sediments equivalent to hard-brown-coal rank at terminal depth.

The reflectance trend for Site 416 (Figure 5) shows a value of about 0.43 per cent $R$ at 1500 meters, at which depth an extrapolated temperature of about $48^{\circ} \mathrm{C}$ is expected (gradient of $30^{\circ} \mathrm{C} / \mathrm{km}+3^{\circ} \mathrm{C}$ at sea floor). This compares with a value of about 0.5 per cent $R$ at 1500 meters and $67^{\circ} \mathrm{C}$ at Site 397 (Cornford et al., in press). The section at Site 397 contains 1300 meters of Miocene and younger sediments, while bottom-hole sediments at Site 416 had been buried to at least 1000 meters by the end of the Cretaceous (Figure 2). It appears that at Site 416 a relatively long effective heating time means that a lower temperature is required to reach a given reflectance level. For example, the last $10^{\circ} \mathrm{C}$ rise in temperature has occurred at Site 397 over the last 4 million years (sedimentation $80 \mathrm{~m} / \mathrm{m} . \mathrm{y}$., gradient $42^{\circ} \mathrm{C} / \mathrm{km}$ ), whereas at Site 416 it has occurred over the last 25 million years (sedimentation about $13 \mathrm{~m} / \mathrm{m} . \mathrm{y}$.; gradient $30^{\circ} \mathrm{C} / \mathrm{km}$ ). The sediment-accumulation rate of interest is that of the upper portion of the section.

\section{Type of Organic Matter}

The organic-matter type is summarized in Table 2 . Only two Tertiary sediments have been analyzed and both yielded so little kerogen concentrate that a reliable assessment of maceral type was difficult: both concentrates appear to contain a mixed vitrinitic (terrestrial) and amorphous (aquatic) kerogen (Table 2).

Of the Mesozoic sediments analyzed at both sites, the four concentrates from the Cenomanian, Hauterivian and upper portion of the Valanginian section contain mostly a dull-fluorescing, amorphous type of liptinitic kerogen (Table 2). This is in contrast to three samples from the lower portion of the Valanginian section and Tithonian which contain mostly vitrinite, inertinite, and particulate liptinites - all macerals of higher-plant (terrestrial) origin.

All samples from Mesozoic sediments, and the sample from the upper Oligocene at Site $416(452 \mathrm{~m})$ came from dominantly turbiditic or slumped sequences (Figure 2). We would expect the organic matter in these sediments to reflect the depositional environment at the origin of the slumps or turbidites, rather than their final resting place. The origin of these allochthonous deposits is, according to the Leg 50 shipboard scientists, on the outer continental shelf or slope. The accumulation of significant quantities of chemically unstable debris from planktonic organisms (as is indicated by the amorphous kerogen type) suggests a reducing environment, such as that found where an oxygen minimum encroaches on the continental shelf (Cornford, in press, a). Evidence for the presence of an oxygen-minimum zone in this region of the Atlantic during the Hauterivian and Eocene 
A

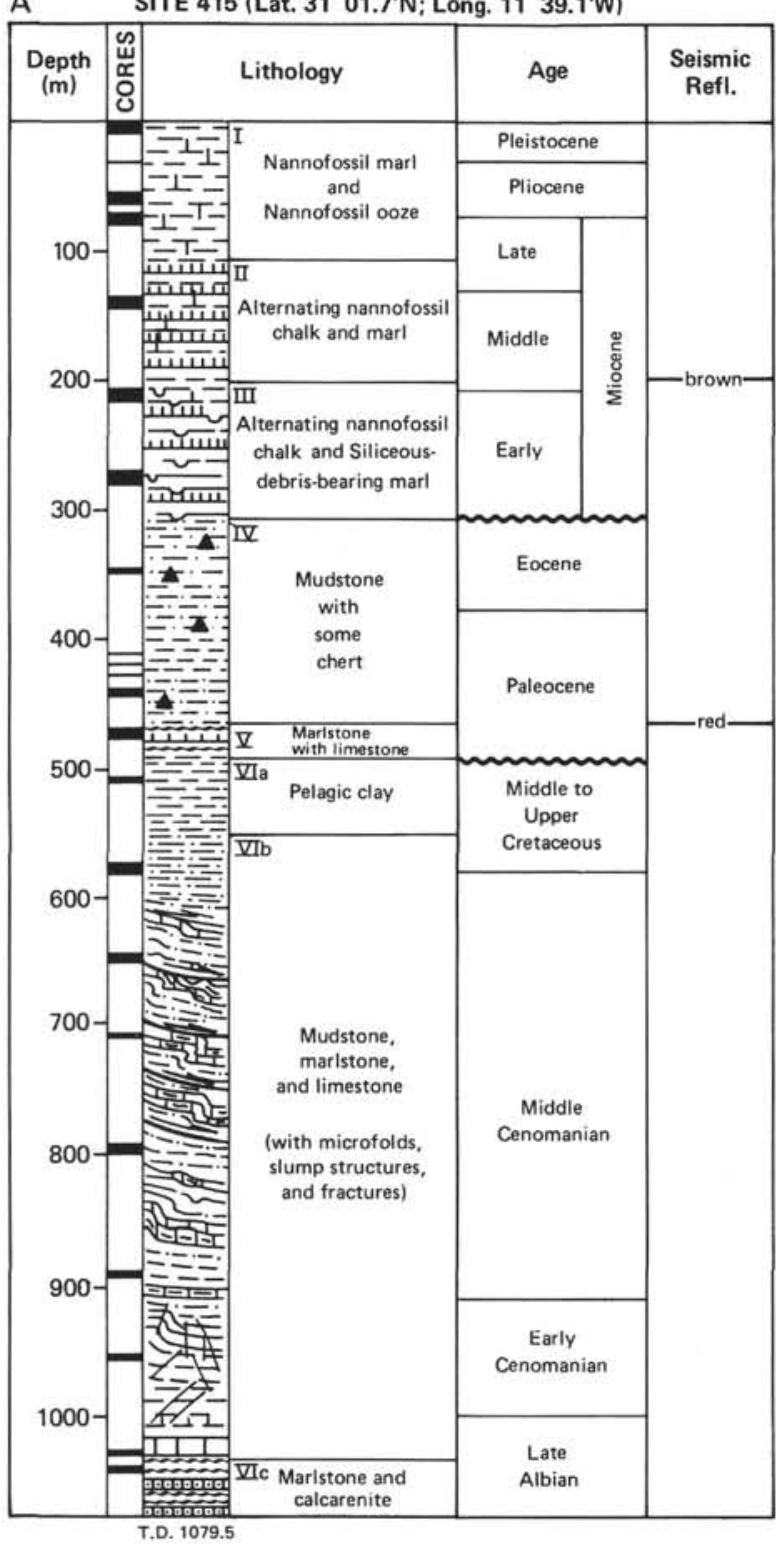

B SITES 416 and 370 (Lat. $3250.2^{\prime} \mathrm{N}$; Long. $1048.1 \mathrm{~W}$ )

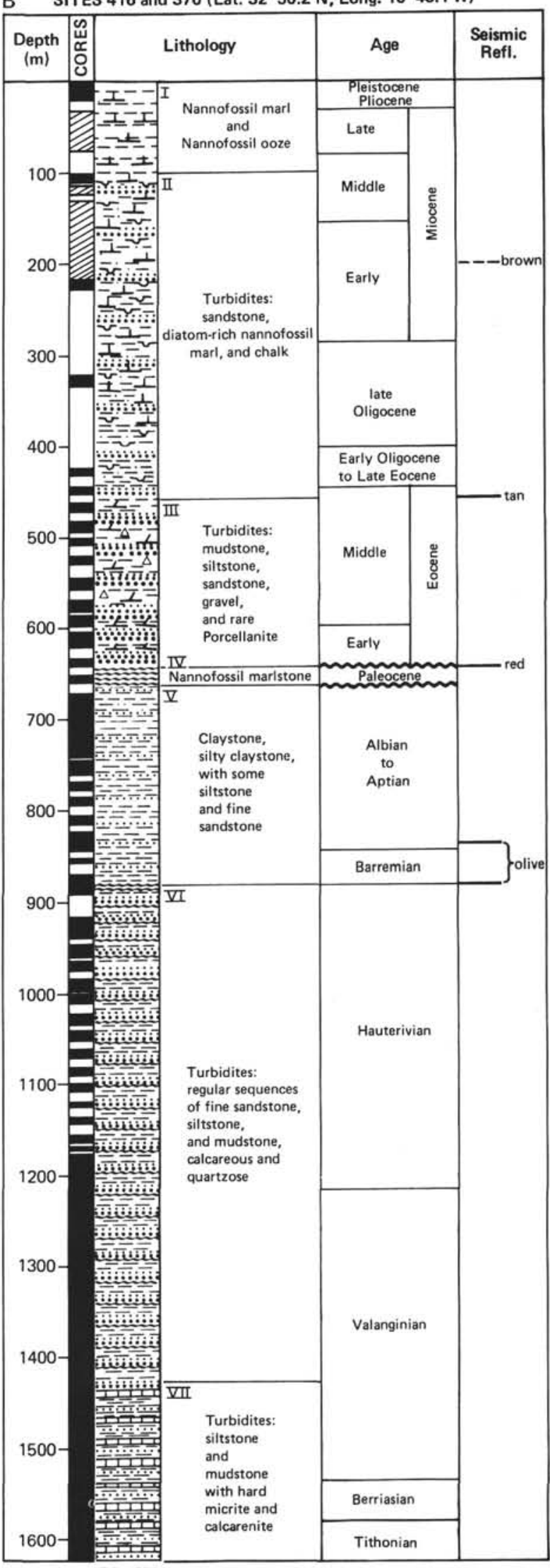

Figure 2. Lithology and stratigraphy at DSDP Site 415 (A) and Sites 416 and 370 (B). 


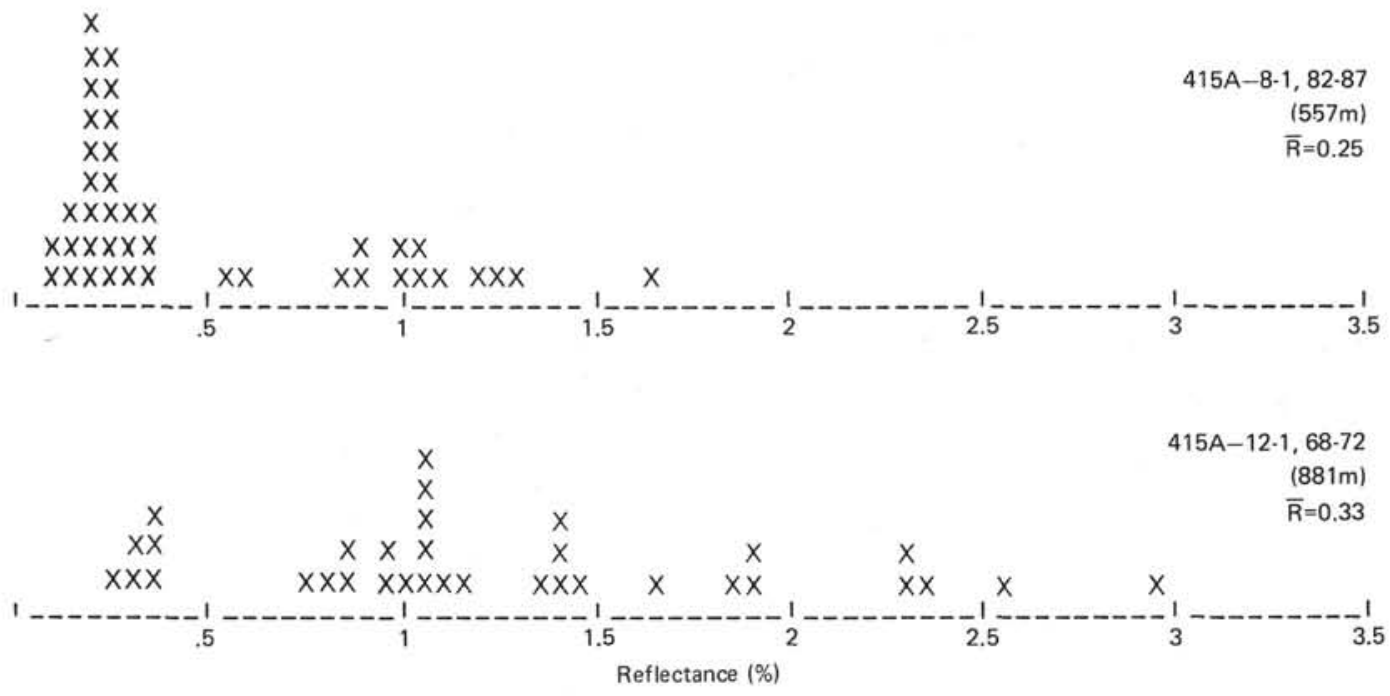

Figure 3. Vitrinite reflectance histograms for samples from DSDP Site 415. Vertical axis $=$ number of counts/reflectance interval.

is provided by accumulation on the outer shelf and slope of amorphous kerogens under a reducing environment. Reconstruction of Mesozoic geography has led Thiede and van Andel (1977) to propose that an oxygen minimum developed in the South Atlantic during the Late Cretaceous, but evidence for the Early Cretaceous is lacking.

Similar slumped sediments containing amorphous and particulate liptinites were found in the Miocene sediments of Site 397, some $800 \mathrm{~km}$ to the south of Site 416 . In contrast to Site 416, the Hauterivian at Site 397 contained a vitrinite-rich kerogen of higher-plant (terrestrial) origin (Cornford, in press, a). At Site 398, to the north (Vigo Seamount), the Hauterivian-Albian strata contained a high organic-carbon content and were dominantly vitrinitic, although some contained appreciable amounts of amorphous kerogen (Cornford, in press, b). A major increase in redeposited kerogen in the Aptian sediments of Site 398 was noted. At Site 416 we see rederived spores (anomalously low fluorescence) and bimodal vitrinite populations in the Valanginian and Tithonian samples (Table 2, Figure 4b). The Mesozoic geographic setting of the Site 398 sediments is not certain. The accumulation of high-organic-carbon sediments is not alone a good indicator of anaerobic conditions, since the organic matter may be highly refractory. Sediments rich in organic carbon of planktonic-organism genesis (chemically unstable) are better evidence for truly anaerobic conditions of deposition.

\section{Petroleum Potential}

From the relatively small number of samples analyzed from these sites, only some general conclusions can be drawn concerning the three prerequisites for good hydrocarbon source rocks: quantity, quality, and maturity of the sedimentary organic matter. Sample $415-8-1,82-87 \mathrm{~cm}$ contains the greatest amount of or- ganic carbon (1.4 per cent), whereas Samples 415-5-3, 73-78 cm; 416A-40-4, 119-124 cm; and 416A-57-1, 131$134 \mathrm{~cm}$ contain the least organic carbon, under 0.26 per cent (Table 2). The remaining samples fall between 0.48 and 0.88 per cent organic carbon. Those sediments richest in amorphous kerogen (Table 2) have the highestquality organic matter. Samples $415 \mathrm{~A}-8-1,82-87 \mathrm{~cm}$ (middle to Upper Cretaceous) and 416A-3-2, 64-69 cm (upper Oligocene) contain the greatest amounts of predominantly amorphous kerogen. These two samples are the best hydrocarbon source rocks of the nine samples analyzed. They are, however, immature in terms of petroleum generation (i.e., vitrinite-reflectance values well under $0.5 \%$, Figure 5) and will not, at Sites 415 or 416 , have started effective hydrocarbon generation.

\section{ACKNOWLEDGMENTS}

I would like to thank Ms. I. Jacobs and Mr. W. Benders for extensive technical help, and my colleagues at Erdöl und Organische Geochemie, Jülich, for constructive criticism in preparing this manuscript. My thanks go to Dr.-Ing. H. Hagemann (Technische Hochschule, Aachen) for reviewing the manuscript.

\section{REFERENCES}

Cornford, C., in press, a. Organic deposition at a continental rise: organic geochemical interpretation and synthesis at DSDP Site 397, eastern North Atlantic. In Ryan, W. B. F., von Rad, U., et al., Initial Reports of the Deep Sea Drilling Project, v. 47, Part 1: Washington (U.S. Government Printing Office).

, in press, b. Organic petrography of DSDP Leg 47B, Site 398, Vigo Seamount eastern North Atlantic. In Ryan, W. B. F., Sibuet, J.-C., et al., Initial Reports of the Deep Sea Drilling Project, v. 47, Part 2: Washington (U.S. Government Printing Office).

Cornford, C. Rullkötter, J., and Welte, D. H., in press. The organic geochemistry of DSDP Leg 47A, Site 397, eastern North Atlantic: organic petrography and extractable hy- 


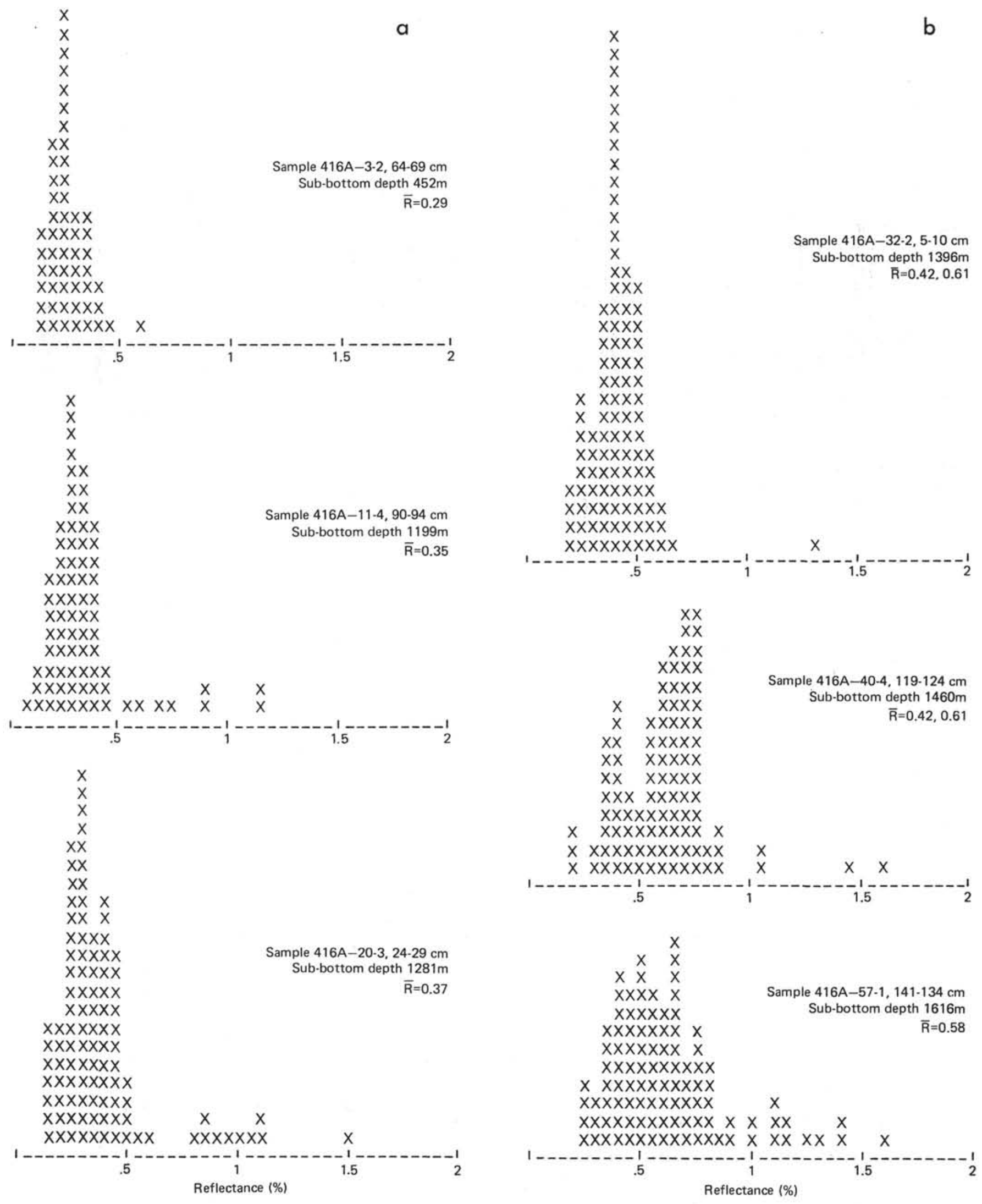

Figure 4. Vitrinite reflectance histograms for samples from DSDP Site 416. (a) 452 to $1281 \mathrm{~m}$; (b) 1396 to $1616 \mathrm{~m}$. 
TABLE 1

Vitrinite-Reflectance Data, DSDP Sites 415 and 416

\begin{tabular}{lccccr}
\hline \multicolumn{1}{c}{$\begin{array}{c}\text { Sample } \\
\text { (Interval in cm) }\end{array}$} & $\begin{array}{c}\text { Depth } \\
(\mathrm{m})\end{array}$ & $\begin{array}{c}\text { Mean } \\
\text { Reflectance } \\
(\%)\end{array}$ & $\begin{array}{c}\text { Range } \\
(\%)\end{array}$ & $\begin{array}{c}\text { Std. } \\
\text { Dev. }\end{array}$ & $N^{\mathrm{a}}$ \\
\hline $415-5-3,73-78$ & 278 & - & - & - & - \\
$415 \mathrm{~A}-8-1,82-87$ & 577 & 0.25 & $0.13-0.36$ & 0.06 & 28 \\
$415 \mathrm{~A}-12-1,67-72$ & 881 & 0.33 & $0.28-0.36$ & 0.03 & 6 \\
$416 \mathrm{~A}-3-2,64-69$ & 452 & 0.29 & $0.21-0.43$ & 0.06 & 46 \\
$416 \mathrm{~A}-11-4,90-94$ & 1199 & 0.35 & $0.25-0.49$ & 0.06 & 57 \\
$416 \mathrm{~A}-20-3,24-29$ & 1281 & 0.37 & $0.25-0.53$ & 0.08 & 79 \\
$416 \mathrm{~A}-32-2,5-10$ & 1396 & 0.43 & $0.26-0.61$ & 0.08 & 99 \\
$416 \mathrm{~A}-40-4,119-124$ & 1460 & 0.42 & $0.32-0.53$ & 0.06 & 29 \\
$416 \mathrm{~A}-57-1,131-134$ & 1616 & 0.47 & $0.31-0.60$ & 0.08 & 50 \\
\hline
\end{tabular}

aN $=$ Number of counts per population.

drocarbons. In Ryan, W. B. F., von Rad, U., et al., Initial Reports of the Deep Sea Drilling Project, v. 47, Part 1: Washington (U.S. Government Printing Office).

Stach, E., Mackowsky, M.-Th., Teichmüller, M., Taylor, G. H., Chandra, D., and Teichmuller, R., 1975. Stach's Textbook of Coal Petrology: Stuttgart (Gebrüder Borntraeger).

Thiede, J. and van Andel, T. H., 1977. The paleoenvironment of anaerobic sediments in the late Mesozoic South Atlantic Ocean, Earth Planet. Sci. Lett., v. 33, p. 301.

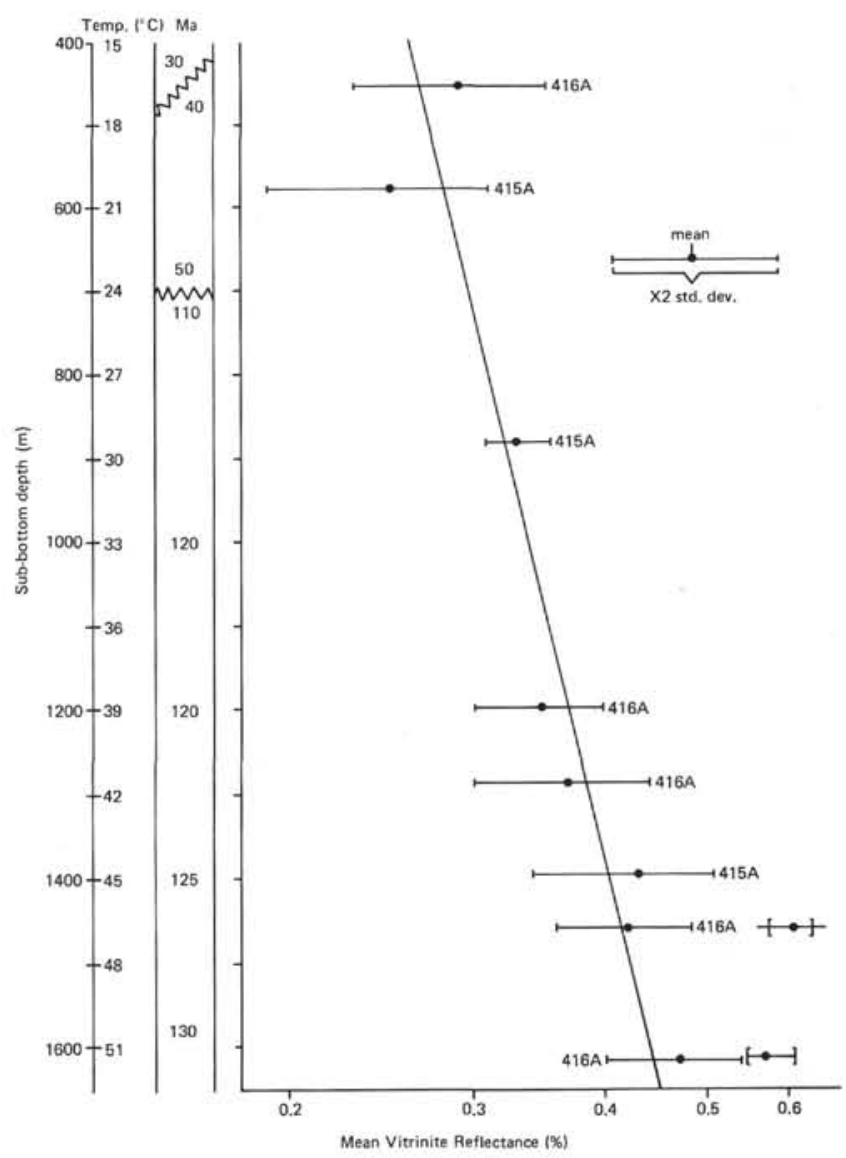

Figure 5. Mean vitrinite reflectance (point) and $2 \times$ standard deviation (bar) as a function of depth at DSDP Sites 415 and 416. Vertical axis also shows temperature $\left({ }^{\circ} \mathrm{C}\right.$ ) and geological time (m.y.) for Site 416 only. Values in square brackets are from a second vitrinite reflectance peak.(Figure $4 b$ ) representing redeposited organic matter, and are ignored in establishing the maturity trend.

TABLE 2

Maceral Analysis and Organic-Carbon Data, DSDP Sites 415 and 416

\begin{tabular}{|c|c|c|c|c|c|c|c|}
\hline \multirow{2}{*}{$\begin{array}{c}\text { Sample } \\
\text { (Interval in } \mathrm{cm} \text { ) }\end{array}$} & \multirow{2}{*}{$\begin{array}{l}\text { Depth } \\
\text { (m) }\end{array}$} & \multirow[b]{2}{*}{ Time-Rock Unit } & \multirow{2}{*}{$\begin{array}{l}\mathrm{C} \\
(\%)\end{array}$} & \multicolumn{3}{|c|}{ Maceral Analysis ${ }^{\mathrm{a}}$} & \multirow[b]{2}{*}{ Comments } \\
\hline & & & & $\mathrm{V}(\%)$ & I $(\%)$ & $\mathrm{L}(\%)$ & \\
\hline $415-5-3,73-78$ & 278 & Lower Miocene & 0.15 & 50 & 1 & 50 & Poor concentrate recovery \\
\hline $\begin{array}{l}415 A-8-1,82-87 \\
415 A-12-1,68-72 \\
416 A-3-2,64-69 \\
416 A-11-4,90-94 \\
416 A-20-3,24-29\end{array}$ & $\begin{array}{r}577 \\
881 \\
452 \\
1199 \\
1281\end{array}$ & $\begin{array}{l}\text { M.-U. Cret. } \\
\text { Cenomanian } \\
\text { U. Oligocene } \\
\text { Hauterivian } \\
\text { Valanginian }\end{array}$ & $\begin{array}{l}1.40 \\
0.61 \\
0.88 \\
0.58 \\
0.55\end{array}$ & $\begin{array}{r}5 \\
30 \\
40 \\
30 \\
45\end{array}$ & $\begin{array}{r}1 \\
10 \\
1 \\
1 \\
5\end{array}$ & $\begin{array}{l}95 \\
60 \\
60 \\
70 \\
50\end{array}$ & $\begin{array}{l}\text { Liptinite predominantly } \\
\text { amorphous with dull } \\
\text { fluorescence }\end{array}$ \\
\hline $\begin{array}{l}416 \mathrm{~A}-32-2,5-10 \\
416 \mathrm{~A}-40-4,119-124 \\
416 \mathrm{~A}-57-1,131-134\end{array}$ & $\begin{array}{l}1396 \\
1460 \\
1616\end{array}$ & $\begin{array}{l}\text { Valanginian } \\
\text { Valanginian } \\
\text { Tithonian }\end{array}$ & $\begin{array}{l}0.48 \\
0.22 \\
0.26\end{array}$ & $\begin{array}{l}75 \\
80 \\
80\end{array}$ & $\begin{array}{r}5 \\
5 \\
10\end{array}$ & $\begin{array}{l}20 \\
15 \\
10\end{array}$ & $\begin{array}{l}\text { Liptinite mixed } \\
\text { amorphous + particulate: } \\
\text { rederived spores }\end{array}$ \\
\hline
\end{tabular}

av $=$ Vitrinite + Huminite, $\mathrm{I}=$ Inertinite, $\mathrm{L}=$ Liptinite. 